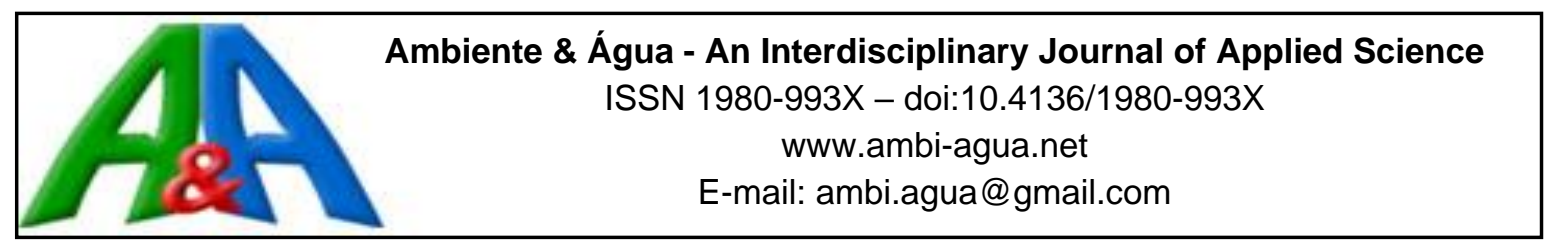

\title{
Comparative characterization of humic substances extracted from freshwater and peat of different apparent molecular sizes
}

\author{
doi:10.4136/ambi-agua.2022
}

Received: 05 Oct. 2016; Accepted: 07 Jul. 2017

\author{
Eliane Sloboda Rigobello ${ }^{1 *}$; Sandro Xavier Campos²; \\ Eduardo Ribeiro de Azevedo ${ }^{3}$; Angela Di Bernardo Dantas ${ }^{4}$; \\ Eny Maria Vieira ${ }^{5}$
}

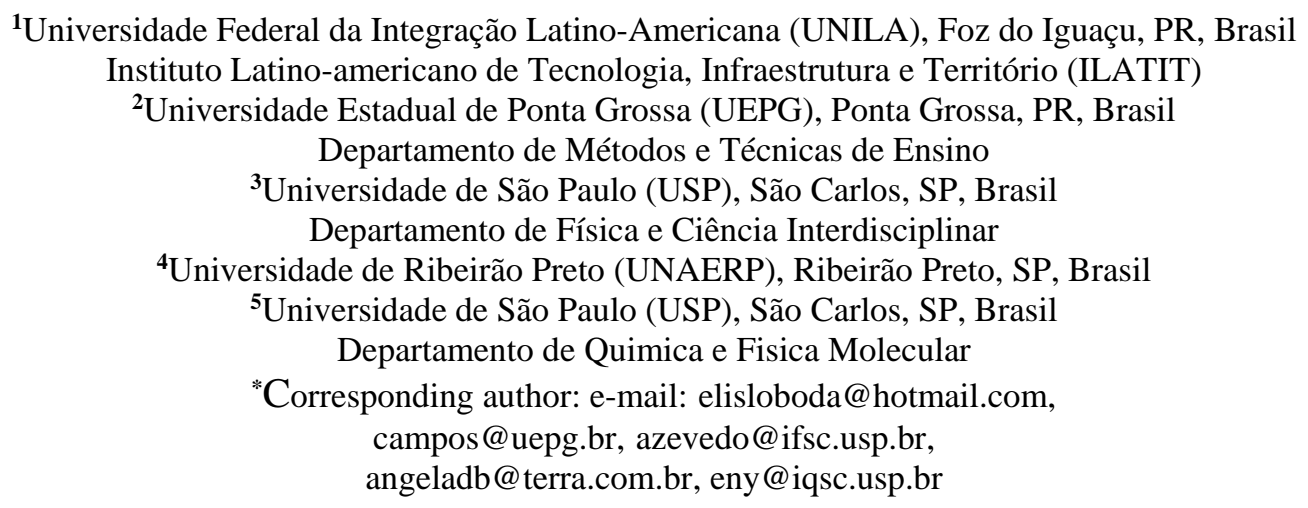

\begin{abstract}
This paper compares the structural characteristics of aquatic humic substances (AHS) with humic substances from peat (HSP) through different analytical techniques, including elemental analysis, solid state ${ }^{13} \mathrm{C}$ cross polarization/magic-angle-spinning nuclear magnetic resonance spectroscopy $\left({ }^{13} \mathrm{C}\right.$ CP-MAS NMR), ultraviolet/visible (UV/Vis) spectroscopy and Fourier transform infrared (FTIR) spectroscopy and total organic carbon (TOC). The AHS were extracted from water collected in a tributary of the Itapanhaú River (Bertioga/SP) using XAD 8 resin, and the HSP were extracted from peat collected in the Mogi Guaçu River bank (Luis Antonio/SP) with a $\mathrm{KOH}$ solution. After dialysis, both AHS and HSP extracts were filtered in membrane of $0.45 \mu \mathrm{m}$ pore size (Fraction $\mathrm{F} 1:<0.45 \mu \mathrm{m}$ ) and fractioned by ultrafiltration in different apparent molecular sizes (AMS) (F2: $100 \mathrm{kDa}-0.45 \mu \mathrm{m}$; F3: $30 \mathrm{kDa}-100 \mathrm{kDa}$ and F4: $<30 \mathrm{kDa}$ ). The extracts with the lowest AMS (F3 and F4) showed a higher number of aliphatic carbons than aromatic carbons, a higher concentration of groups containing oxygen and a higher percentage of fulvic acids (FA) than humic acids (HA) for both AHS and HSP. However, the AHS presented higher FA than HA content in relation to the HSP and distinct structural properties.
\end{abstract}

Keywords: fulvic acid, humic acid, humic substances, ultrafiltration. 


\section{Caracterização comparativa de substâncias húmicas extraídas de água e de turfa de diferentes tamanhos moleculares aparentes}

\section{RESUMO}

Este artigo compara as características estruturais das substâncias húmicas aquáticas (SHA) com substâncias húmicas de turfa (SHT) usando diferentes técnicas analíticas, incluindo análise elementar, espectro de polarização cruzada de estado sólido ${ }^{13} \mathrm{C} /$ espectroscopia de ressonância magnética nuclear $\left({ }^{13} \mathrm{C} \mathrm{CP}-\mathrm{MAS} \mathrm{RMN}\right)$, espectroscopia no ultravioleta/visível e infravermelho com transformada de Fourier e carbono orgânico total (COT). As SHA foram extraídas de água coletada em um afluente do rio Itapanhaú (Bertioga/SP), utilizando resina XAD 8 e as SHT foram extraídas de turfa coletadas na margem do rio Mogi-Guaçu (Luis Antonio/SP) com uma solução de KOH. Após a diálise, ambos extratos de SHA e SHT foram filtrados em membrana com 0,45 $\mu \mathrm{m}$ de tamanho de poro (Fração F1: $<0,45 \mu \mathrm{m}$ ) e após fracionados através de ultrafiltração em diferentes tamanhos moleculares aparentes (F2: $100 \mathrm{kDa}-0,45 \mu \mathrm{m} ; \mathrm{F} 3: 30$ $100 \mathrm{kDa}$ e F4: < $30 \mathrm{kDa}$ ). Os extratos de menor tamanho (F3 e F4) apresentaram um maior número de átomos de carbono alifáticos do que de carbonos aromáticos, uma maior concentração de grupos contendo oxigênio e uma percentagem mais elevada de ácidos fúlvicos do que os ácidos húmicos para ambas as frações de SHA e de SHT. No entanto, as SHA apresentaram maior quantidade de ácidos fúlvicos que ácidos húmicos em relação às SHT e propriedades estruturais distintas.

Palavras-chave: ácidos fúlvicos, ácidos húmicos, substâncias húmicas, ultrafiltração.

\section{INTRODUCTION}

Humic substances (HS) found in soils, peats, sediments and natural waters come from the chemical and biological degradation of plants and animals residues in the environment and the synthesis activity of microorganisms (McDonald et al., 2004). The properties and structure of HS may vary substantially, depending on the characteristics of the water or soil, of the compounds of origin, maturation of the HS and specific conditions of extraction (Fong and Mohamed, 2007; Muscolo et al., 2013; Garcia et al., 2016). Aquatic humic substances (AHS) can be formed directly in the aquatic environment, or from HS present in soils and sediments and transported to the waters by processes of lixiviation and surface runoff (Yang et al., 2007).

In general, both AHS and humic substances from peat (HSP) can be considered biogenic organic substances, poly-electrolyte with properties that are similar to bio-colloids, such as dark coloration, heterogeneous nature, high molecular weight, many different molecular sizes (poly-dispersity), refractory, partially biodegradable and with a complex structure (McDonald et al., 2004; Muscolo et al., 2013; Wagner et al., 2016).

According to Piccolo (2001), Diallo et al. (2003) and Sutton et al. (2005), HS are formed by small and heterogeneous molecules of various origins, self-organized in supramolecular conformations, which would explain the large molecular size of SH. Fischer (2017) proved the hypothesis that HS in native soils are spatially arranged in descending order of polarity, meaning that highly polar supramolecular subunits shield less polar subunits against the free soil solution and form layers of descending polarity. However, due to the complexity of HS and different chemical and environmental factors, it is difficult to accurately determine the structure and molecular size of these substances.

HS are classified into three main fractions, based on their solubilities: humic acids (HA), which are soluble in alkali, but insoluble in acid; fulvic acids (FA), soluble in alkali and acid; and humins, insoluble in both. In surface water, approximately $90 \%$ of the HS occur as FA, and only $10 \%$ or less as HA (Rigobello et al., 2011). These fractions vary in molecular size and 
functional group content. HA are generally larger in size than FA in HS isolated from both water (Samios et al., 2007) and peat (Fong and Mohamed, 2007).

The HS have been evaluated in different studies, such as in agriculture, transport of contaminants in the environment, metal complexation and drinking water treatment (Araújo et al., 2002; Samios et al., 2007; Campos et al., 2007; Rigobello et al., 2011; Sachs and Bernhard, 2011; Muscolo et al., 2013). When using chlorine, HS lead to a high demand of the disinfectant, as well as the formation of toxic halogenated byproducts as trihalomethanes (Pascoalatto et al., 2008). Studies in water using HSP may provide different results due to the different characteristics of the AHS and HSP. Thus, the comparative characterization of AHS and HSP, including physicochemical analysis, spectroscopic methods and molecular size fractionation methods, is relevant for understanding the structural and functional properties of each HS and the reactivity of these substances in aquatic and terrestrial environments.

This article compares the characteristics of HS of different apparent molecular sizes (AMS) isolated from water and from peat using complementary analytical techniques.

\section{MATERIALS AND METHODS}

\subsection{Isolation and fractionation of AHS and HSP}

The AHS were isolated from the water collected in a tributary of the Itapanhaú River (2347'19,35" S; 46³'29,32" W) in Bertioga, São Paulo, Brazil (tropical forest) by adsorption on XAD-8 non-ionic macroporous resin (Supelco) column at pH 2.0, which has great affinity for hydrophobic organic acids, according to the method of Thurman and Malcolm (1981). The water samples exhibited a true color of $330 \mathrm{HU}$, turbidity of $2.78 \mathrm{NTU}, \mathrm{pH}=5.7$, DOC of $22.6 \mathrm{mg} \mathrm{C} \mathrm{L}^{-1}$, alkalinity of $6 \mathrm{mg} \mathrm{CaCO}_{3} \mathrm{~L}^{-1}$ and $\mathrm{UV}$ absorbance at a wavelength of $254 \mathrm{~nm}$ (UV254) of 1.17.

The HSP were isolated from peat soil (40 cm deep) collected from a peat soil located near the Mogi Guaçu River (2135'53.2" S; 4757'03.3" W), Km 40, SP-255, Luís Antônio, Brazil (Environmentally Protected Area). After drying, the peat samples were coarsely ground in an agate mortar and stored in a closed polyethylene vessel. The method used for the extraction of HSP was developed by Rosa et al. (2000), described as follows: (a) $50 \mathrm{~g}$ of peat was added in one liter of $\mathrm{KOH}$ at $0.5 \mathrm{~mol} \mathrm{~L}-1$ concentration and stirred for $4 \mathrm{~h}$ at room temperature $\left(25^{\circ} \mathrm{C}\right)$; (b) the solution obtained was allowed to settle for $48 \mathrm{~h}$; (c) the $\mathrm{pH}$ of the supernatant was adjusted with $\mathrm{HCl} 0.1 \mathrm{~mol} \mathrm{~L}^{-1}$ to approximately 6.0 and (d) the supernatant was stored in semipermeable paper bags and submitted to dialysis in water deionized until negative test for chloride (using an $\mathrm{AgNO}_{3}$-based test). After dialysis, both AHS and extracts were filtered through a $0.45 \mu \mathrm{m}$ pore size membrane (Millipore, cellulose ester, $90 \mathrm{~mm}$ in diameter). The samples were separated into different AMS fractions by tangential ultrafiltration (TFU) using cross flow cassette apparatus (Vivaflow 50, Satorius group) with polyethersulfone membranes as described in Campos et al., (2007). The following nominal cut off fractions were obtained: F1: $<0.45 \mu \mathrm{m}, \mathrm{F} 2: 100 \mathrm{kDa}-0.45 \mu \mathrm{m}, \mathrm{F} 3: 30-100 \mathrm{kDa}$ and F4: $<30 \mathrm{kDa}$. Samples of all fractions were freeze-dried for characterization analysis.

\subsection{Characterization of AHS and HSP}

\subsubsection{Elemental analysis}

The percentages of $\mathrm{C}, \mathrm{H}, \mathrm{N}$ and $\mathrm{S}$ of the AHS and HSP factions were measured by dry combustion in a CHNSO-CE, Perkin Elmer, EA 1110 elemental analyzer. The percentage of O was obtained by difference according to the following expression: $\% \mathrm{O}=[100 \%-(\% \mathrm{C}+\% \mathrm{H}+$ $\% \mathrm{~N}+\% \mathrm{~S})]$. 


\subsubsection{Ash content}

Samples of $10 \mathrm{mg}$ of lyophilized AHS and HSP extracts were calcined at $800{ }^{\circ} \mathrm{C}$ in a muffle EDG Brand 1800-3P for 4h. The organic matter content was then calculated by mass difference, considering the final residue inorganic matter.

\subsubsection{Dissolved organic carbon (DOC)}

The extracts of AHS and HSP were acidified to $\mathrm{pH}<2.0$ with $\mathrm{HCl}$ and left to stand for 24h. They were then separated by centrifugation in FA and HA and DOC concentration was determined by dry combustion in a total organic carbon analyzer, Shimadzu TOC-5000.

\subsubsection{Ultraviolet/visible (UV/Vis) spectroscopy}

HS samples $\left(2 \mathrm{mg}\right.$ ) were dissolved in $25 \mathrm{ml}$ of a $0.05 \mathrm{~mol} \mathrm{~L}^{-1} \mathrm{NaHCO}_{3}$ solution. Spectra of the samples were recorded at 200-800 nm with a UV/Vis spectrophotometer (Hitachi U3501). Absorbance values were measured at 465 and $665 \mathrm{~nm}\left(\mathrm{E}_{4} / \mathrm{E}_{6}\right.$ ratio) and at 250 and 365 $\mathrm{nm}\left(\mathrm{E}_{2} / \mathrm{E}_{3}\right.$ ratio $)$.

\subsubsection{Fourier transform infrared (FTIR) spectroscopy}

FTIR spectra were obtained for a wave number range of 4000 to $1000 \mathrm{~cm}^{-1}$ using a Bomem MB-102 spectrometer. The samples were prepared for analysis by mixing $100 \mathrm{mg}$ of $\mathrm{KBr}$ with $1.0 \mathrm{mg}$ of the humic material and then compressing the mixture to form pellets. The spectra were acquired with 16 scans of $4 \mathrm{~cm}^{-1}$ resolution.

\subsection{6. ${ }^{13} \mathrm{C}$ nuclear magnetic resonance $\left({ }^{13} \mathrm{C}\right.$ CP-MAS NMR) spectroscopy}

The solid state ${ }^{13} \mathrm{C}$ NMR spectra of the AHS and HSP were acquired in a VARIAN unit INOVA spectrometer operating at $100 \mathrm{MHz}$ and $400 \mathrm{MHz}$ for ${ }^{13} \mathrm{C}$. A magic-angle spinning at $5 \mathrm{kHz}$ was used in all experiments. Cross-polarization excitation using a radiofrequency ramp (ramp CP/MAS) Q2, combined with Total Suppression of Q3 Spinning Sidebands (TOSS) acquisition was used. The ramp CP/MAS/TOSS ${ }^{13} \mathrm{C}$ signals were obtained at a contact time of $1 \mathrm{~ms}$, acquisition times of $15 \mathrm{~ms}$, and recycle delays of $0.5 \mathrm{~s}$ (Campos et al., 2007).

\section{RESULTS AND DISCUSSION}

\subsection{Ash content}

The ash content for the F1 fraction $(<0.45 \mu \mathrm{m})$ of AHS was approximately $29.7 \%$ and the smaller fraction studied, F4 $(<30 \mathrm{kDa})$, was $17.4 \%$. The F1 fraction of HSP of the ash content was approximately $27.3 \%$, and for the F4 fraction $28.8 \%$. These results are below those found in Mylotte et al. (2015), in which different methods of SH extraction were used.

In the case of heterogeneous and complex substances, such as HS, the ash content is generally used as an indicator of the amount of inorganic compounds present in the sample or purity of the sample. In this study, and in order to avoid possible chemical changes, the HS was not purified.

\subsection{DOC content in the AHS and HSP fractions}

Table 1 shows the DOC concentrations in the different fractions of AHS and HSP under study. The smallest fraction of AHS, F4, was composed entirely of FA. The opposite was observed for the highest HSP fraction (F1). The highest HA percentage for HSP was obtained in the F2 fraction, with approximately $93 \%$. The highest FA percentage in relation to HA was found in fractions F3 (73\%) and F4 of HSP (88\%). Therefore, generally in fractions of AHS there is more FA than AH. The opposite was observed for HSP. 
The comparison of the data in Table 1 shows that the HA percentage in the F1 fraction of AHS (fraction containing all sizes) is greater than FA, and the opposite was observed for HSP.

Table 1. DOC content in the AHS and HSP fractions of different apparent molecular sizes.

\begin{tabular}{|c|c|c|c|c|c|c|}
\hline \multirow{2}{*}{ HS fractions } & \multicolumn{3}{|c|}{ AHS } & \multicolumn{3}{|c|}{ HSP } \\
\hline & $\mathrm{DOC}\left(\mathrm{mg} \mathrm{L}^{-1}\right)$ & FA $(\%)$ & $\mathrm{HA}^{*}(\%)$ & $\mathrm{DOC}\left(\mathrm{mg} \mathrm{L}^{-1}\right)$ & FA $(\%)$ & $\mathrm{HA}^{*}(\%)$ \\
\hline F1 & 106.3 & 69 & 31 & 320.7 & 14 & 86 \\
\hline F2 & 31.7 & 8 & 92 & 245.3 & 7 & 93 \\
\hline F3 & 24.7 & 86 & 14 & 38.2 & 73 & 27 \\
\hline $\mathrm{F} 4$ & 49.2 & 100 & 0 & 18.9 & 88 & 12 \\
\hline
\end{tabular}

*HA $=$ total-FA

\subsection{Elemental analysis}

Table 2 shows the results of the elemental analysis of AHS and HSP fractions with the calculated atomic ratios.

Table 2. Elemental composition of AHS and HSP.

\begin{tabular}{|c|c|c|c|c|c|c|c|c|c|c|c|c|c|c|}
\hline \multirow{3}{*}{$\begin{array}{c}\text { HS } \\
\text { fractions }\end{array}$} & \multicolumn{8}{|c|}{ Mass $\%$} & \multicolumn{6}{|c|}{ Atomic ratios } \\
\hline & \multicolumn{4}{|c|}{ AHS } & \multicolumn{4}{|c|}{ HSP } & \multicolumn{3}{|c|}{ AHS } & \multicolumn{3}{|c|}{ HSP } \\
\hline & C & $\mathrm{H}$ & $\mathrm{N}$ & $\mathrm{O}$ & C & $\mathrm{H}$ & $\mathrm{N}$ & $\mathrm{O}$ & $\mathrm{H} / \mathrm{C}$ & $\mathrm{O} / \mathrm{C}$ & $\mathrm{C} / \mathrm{N}$ & $\mathrm{H} / \mathrm{C}$ & $\mathrm{O} / \mathrm{C}$ & $\mathrm{C} / \mathrm{N}$ \\
\hline F1 & 37.3 & 3.3 & 1.4 & 57.9 & 41.4 & 4.1 & 1.6 & 52.8 & 1.1 & 1.2 & 30.2 & 1.2 & 0.95 & 29.7 \\
\hline F2 & 36.0 & 3.3 & 1.3 & 59.4 & 44.4 & 4.4 & 2.0 & 49.2 & 1.1 & 1.2 & 32.6 & 1.2 & 0.83 & 26.4 \\
\hline F3 & 37.4 & 3.6 & 0.9 & 58.1 & 36.1 & 4.1 & 1.7 & 58.1 & 1.1 & 1.2 & 48.1 & 1.4 & 1.2 & 25.0 \\
\hline F4 & 35.5 & 4.5 & 0.7 & 59.3 & 26.5 & 3.7 & 1.1 & 68.6 & 1.5 & 1.3 & 58.9 & 1.7 & 1.9 & 27.6 \\
\hline
\end{tabular}

The content of $\mathrm{C}, \mathrm{H}, \mathrm{O}, \mathrm{N}$, and $\mathrm{S}$ provides essential information on the origin of the sample. The $\mathrm{H} / \mathrm{C}, \mathrm{O} / \mathrm{C}$ and $\mathrm{C} / \mathrm{N}$ atomic ratios indicate the structure and the molecular shape of the HS. The lower $\mathrm{H} / \mathrm{C}$ ratio indicates a larger amount of unsaturated structures. In other words, an increase in the hydrogen content indicates a greater number of aliphatic carbons $\left(\mathrm{CH}_{2}\right)$ than aromatic carbons $(\mathrm{C}=\mathrm{C})$ (Traina et al., 1990). Among the AHS and HSP fractions, F1 and F2 showed lower $\mathrm{H} / \mathrm{C}$ atomic ratios, indicating more aromatic fractions. The $\mathrm{H} / \mathrm{C}$ and $\mathrm{O} / \mathrm{C}$ ratios are generally lower for HA than for FA (Bravard and Richi, 1991), as observed for the AHS and HSP fractions (Table 2). The $\mathrm{O} / \mathrm{C}$ atomic ratio is related to the carbohydrate and carboxylic acid contents (both aromatic and aliphatic) and degree of oxidation of the HS. The lower values of this ratio indicate a higher degree of humification due to the reduction in the carbohydrate content in the O-bearing structures (polysaccharides).

The $\mathrm{C} / \mathrm{N}$ atomic ratio indicates a seasonal influence on the degree of humification of the AHS. The O/C values for F1 and F2 fractions of HSP are slightly lower than the values for the same AHS fractions. The $\mathrm{C} / \mathrm{N}$ ratios of the AHS fractions were considerably greater than those of the HSP, indicating that the largest contribution to the humification of AHS resulted from the decomposition of vascular plants (Rocha et al., 2007).

In general, the elemental analysis results (Table 2) indicate that smaller molecular size fractions contain a larger aliphatic proportion than aromatic carbon atoms and a relatively high percentage of oxygen atoms bound to alkyl groups and carboxylic acid. Sulfur was not detected in the HS samples investigated. 
Our study showed some similarities to some results of characterization mentioned in Araújo et al. (2002), who also studied AHS from the Itapanhaú River. The results indicated a higher O/C ratio, particularly in F1 fraction of AHS than F1 fraction of HSP, implying that, as a whole, the AHS are more oxidized and richer in oxygenated groups (carboxylic and phenolic). However, as HS has different chemical characteristics with their origins and with the influence of seasonal conditions, it is difficult to compare the characterization results from different sources.

\subsection{FTIR spectroscopy}

Infrared spectra have been useful for characterizing the nature and distribution of the functional groups in HS (Fuentes et al., 2007; Mylotte et al., 2015; Garcia et al., 2016).

The infrared spectra of the AHS and HSP fractions used in this study are shown in Figure 1. In general, both infrared spectra showed an intense and broad band centered around $3400 \mathrm{~cm}^{-1}$, corresponding to the $\mathrm{OH}$ stretching vibration of carboxylic acids, alcohols, phenols, carbohydrate and the $\mathrm{N}-\mathrm{H}$ stretching vibration of amide and/or amine groups (Samios et al., 2007; Nuzzo, et al., 2013). It was also observed, in the $3000-2800 \mathrm{~cm}^{-1}$ spectral range, characteristic bands that are more intense for F1 and F2 fractions of HSP, corresponding to the $\mathrm{CH}$ symmetric stretching of methyl and/or methylene aliphatic generally overlapping the broad band of stretching $\mathrm{OH}$ (Samios et al., 2007).
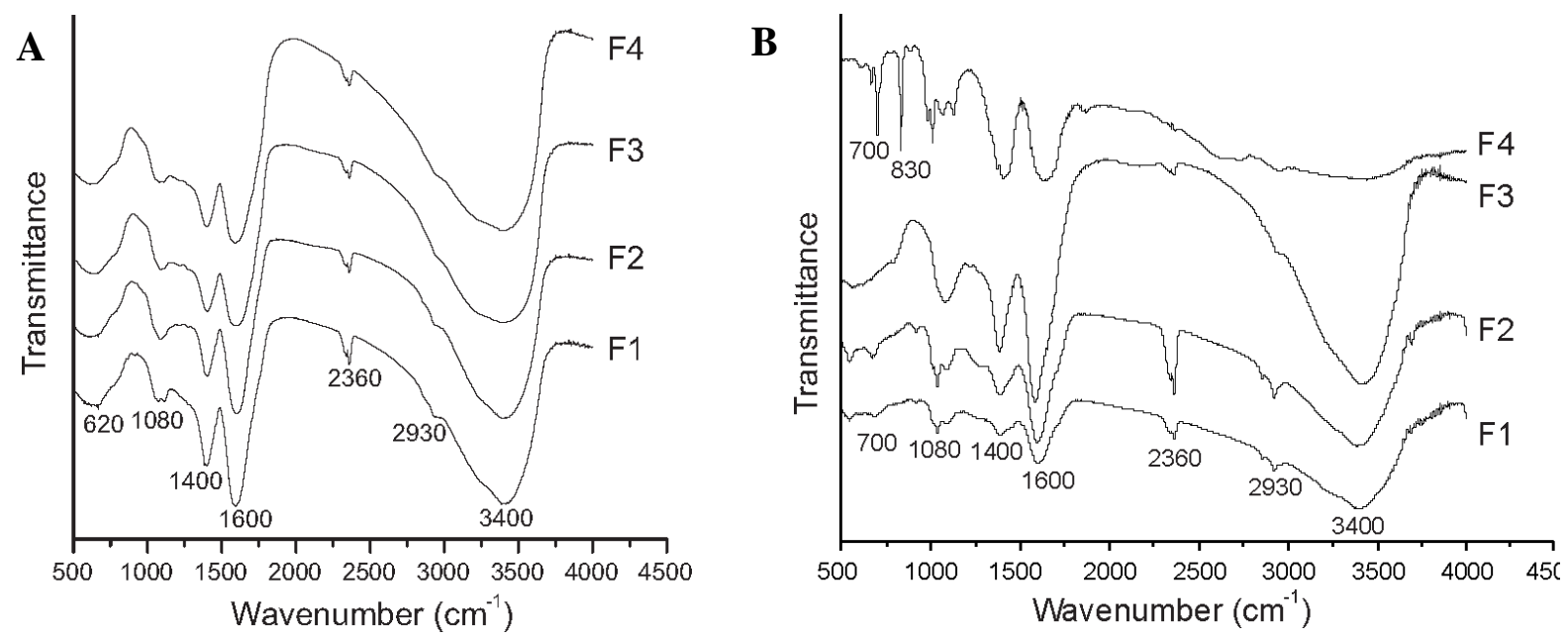

Figure 1. FTIR spectra of AHS (a) and HSP (b) fractions of different apparent molecular sizes.

The band between 1640 and $1620 \mathrm{~cm}^{-1}$ is more complex. In this range, there could be stretching vibrations of $\mathrm{C}=\mathrm{C}$ aromatic bonds, carboxylic asymmetric stretching, amide groups and conjugated carbonyl groups (quinone) (Vergnoux et al., 2011b). At $1465-1440 \mathrm{~cm}^{-1}$ the band indicates the presence of $\mathrm{CH}_{3}$ and $\mathrm{CH}_{2}$ in aliphatic compounds (antisymmetric deformation). The bands near $1400 \mathrm{~cm}^{-1}$ indicate $\mathrm{COO}^{-}$symmetric stretching, $\mathrm{CH}$ symmetric deformation and CO stretching of phenolic OH (Samios et al., 2007; Vergnoux et al., 2011b). In these spectral ranges, absorption bands of similar intensity were observed for all AHS fractions (Fig. 1a) and bands around $1400 \mathrm{~cm}^{-1}$ were more intense in the case of the F3 and F4 fractions of HSP (Figure 1b). Both HS of smaller AMS had higher content of FA (Table 1) and more aliphatic structures. This is also possibly attributed to a lighter content of oxygen containing functional groups (carboxylic, hydroxyl, phenolic) in FA than HA.

Bands were observed in the region between 1100 and $950 \mathrm{~cm}^{-1}$ and can be attributed to $\mathrm{CO}$ stretching of alcohols and/or phenols and/or carbohydrates or even to impurities from silicate (Si-O) (Vergnoux et al., 2011b; Nuzzo, et al., 2013). The spectra obtained for SH studied were 
similar to those found in the literature (Pramanik and Kim, 2014; Mylotte et al., 2015; Garcia et al., 2016), typical bands of humic substances.

\subsection{UV/Vis spectroscopy}

This technique is used to evaluate the aromaticity and humification degree of HS (Silverstein et al., 1994). Table 3 summarizes the $\mathrm{E}_{4} / \mathrm{E}_{6}$ (absorbance at 465 and $665 \mathrm{~nm}$ ) and $\mathrm{E}_{2} / \mathrm{E}_{3}$ (absorbance at 250 and $365 \mathrm{~nm}$ ) atomic rations of the AHS and HSP fractions. Higher $\mathrm{E}_{4} / \mathrm{E}_{6}$ ratios reflect the prominence of aliphatic structures, whereas lower $\mathrm{E}_{4} / \mathrm{E}_{6}$ ratios indicate the dominance of aromatic constituents (McDonald et al., 2004). Higher $\mathrm{E}_{2} / \mathrm{E}_{3}$ ratios are usually associated with lower molecular weight and lower degree of aromaticity (Vergnoux et al., 2011a). The $\mathrm{E}_{4} / \mathrm{E}_{6}$ ratio is influenced by the molecular size, environmental $\mathrm{pH}$, oxygen content, carbon, carboxylic groups, origin and age of the humic material (Stevenson, 1994).

Table 3 shows that the $\mathrm{E}_{4} / \mathrm{E}_{6}$ ratios for the all AHS fractions were similar. For the HSP fractions, they were greater in the smaller fractions (F3 and F4), indicating higher level of aliphatic structures.

The $\mathrm{E}_{2} / \mathrm{E}_{3}$ ratio values for both AHS and HSP fractions were higher for the fractions of smaller AMS, while the opposite occurred with the aromaticity (Table 3). In larger fractions, the number of condensed rings is higher in comparison to the aliphatic structures, due to the high humification degree. When the values of $\mathrm{E}_{4} / \mathrm{E}_{6}$ and $\mathrm{E}_{2} / \mathrm{E}_{3}$ ratios are compared, the same tendency is observed, that is, the larger the molar mass, the higher its condensation degree and aromaticity. The $\mathrm{E}_{4} / \mathrm{E}_{6}$ ratio values for the $\mathrm{F} 2$ fraction of AHS and of HSP were lower than the value found for the F1, F3 and F4 fractions, as the F1 fraction absorbed less at 465 and $665 \mathrm{~nm}$ in relation to the $\mathrm{F} 2$ fraction. To indicate the aromaticity of the molecule, an equation suggested by Peuravuori and Pihlaja (1997) was used, in which aromaticity $=52.5-6.78 \mathrm{E}_{2} / \mathrm{E}_{3}$.

Table 3. Analysis of UV/Vis spectroscopy for AHS and HSP.

\begin{tabular}{|c|c|c|c|c|c|c|}
\hline \multirow{3}{*}{ Fractions } & \multicolumn{3}{|c|}{ AHS } & \multicolumn{3}{|c|}{ HSP } \\
\hline & Ratio & Ratio & \multirow{2}{*}{ Aromaticity } & Ratio & Ratio & \multirow{2}{*}{ Aromaticity } \\
\hline & $\mathrm{E}_{4} / \mathrm{E}_{6}$ & $\mathrm{E}_{2} / \mathrm{E}_{3}$ & & $\mathrm{E}_{4} / \mathrm{E}_{6}$ & $\mathrm{E}_{2} / \mathrm{E}_{3}$ & \\
\hline $\mathrm{F} 1$ & 8.40 & 3.16 & 31.07 & 3.26 & 2.46 & 35.82 \\
\hline $\mathrm{F} 2$ & 6.07 & 3.06 & 31.75 & 3.10 & 2.39 & 36.29 \\
\hline F3 & 8.23 & 3.11 & 31.41 & 5.40 & 3.13 & 31.27 \\
\hline $\mathrm{F} 4$ & 8.40 & 3.94 & 25.78 & 8.86 & 3.95 & 25.72 \\
\hline
\end{tabular}

\section{6. ${ }^{13} \mathrm{C}$ CPMAS-NMR spectroscopy}

Figure 2 shows the NMR spectra obtained for samples of AHS and HSP fractionated at different AMS and the relative intensities for each spectral region are shown in Table 4.

In general, the NMR spectra in Figure 2 show that, mainly for the AHS, the peaks were very similar and characteristic of $\mathrm{HS}$, presenting signals which can be associated with the different functional aliphatic $\left(\mathrm{C}-\mathrm{H}, \mathrm{C}-\mathrm{N}, \mathrm{O}-\mathrm{CH}_{3}\right.$, polysaccharides $)$ and aromatic $(\mathrm{C}-\mathrm{H}$ and phenolic) groups. The peaks observed have been frequently reported by other researchers who have used ${ }^{13} \mathrm{C}$ NMR to characterize HS (González-Pérez, et al., 2008; Esteves et al., 2009; Rosa et al., 2011; Schneckenburger et al., 2012; Myllote et al., 2015; Garcia et al., 2016). 

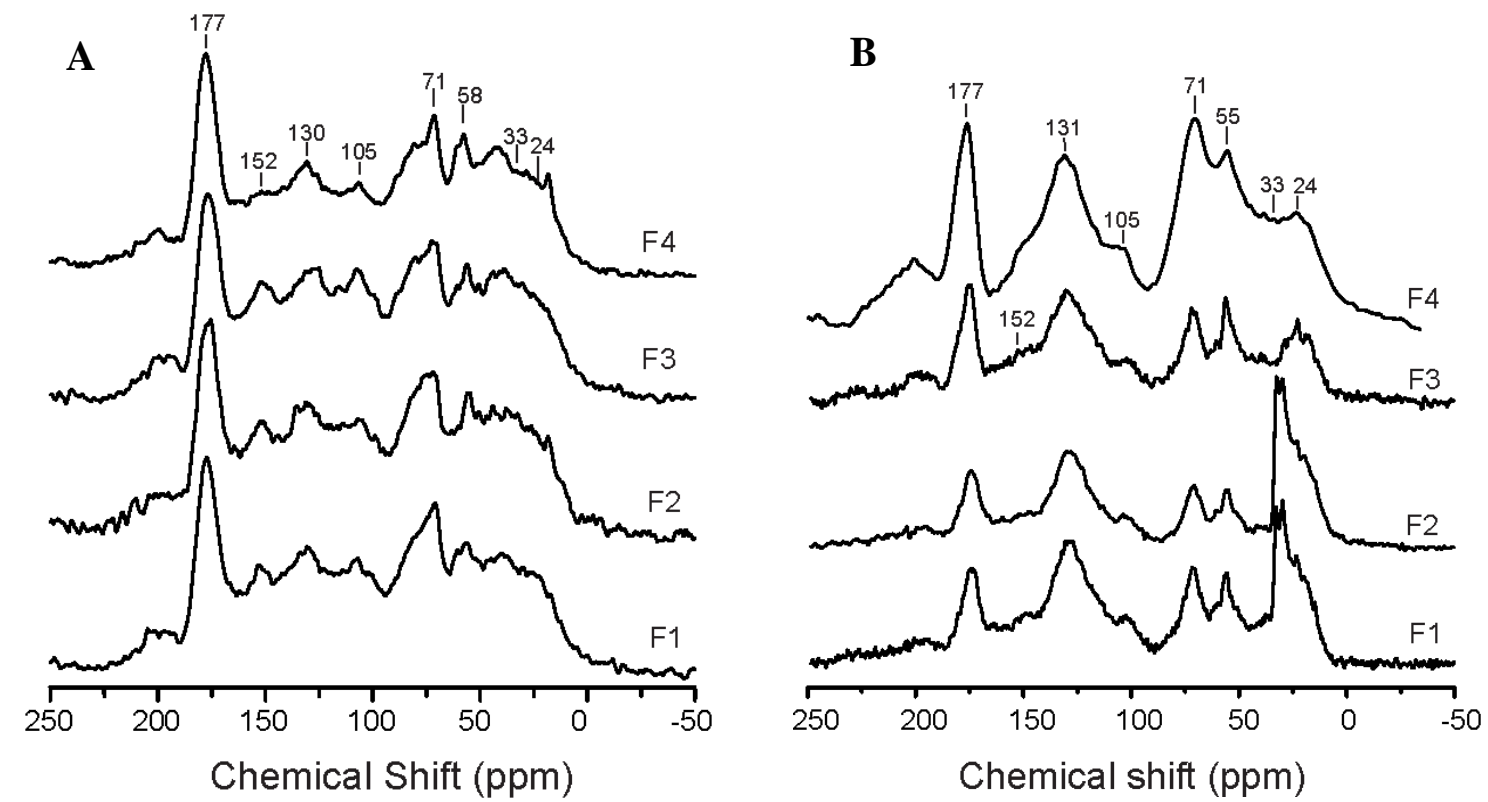

Figure 2. CPMAS- ${ }^{13} \mathrm{C}$ NMR spectra corresponding to AHS (a) and HSP (b) fractions of different apparent molecular sizes.

Table 4. Percentage NMR intensities observed along the different spectral regions for samples fractionated with different apparent molecular sizes.

\begin{tabular}{|c|c|c|c|c|c|c|c|c|c|c|c|c|}
\hline \multirow{4}{*}{$\begin{array}{c}\text { HS } \\
\text { Fraction }\end{array}$} & \multicolumn{12}{|c|}{ Percentage NMR intensities relative to different spectral regions } \\
\hline & \multicolumn{10}{|c|}{ Chemical shift (ppm) } & & \\
\hline & \multicolumn{2}{|c|}{$0-45$} & \multicolumn{2}{|c|}{$45-60$} & \multicolumn{2}{|c|}{$60-110$} & \multicolumn{2}{|c|}{$110-160$} & \multicolumn{2}{|c|}{$160-185$} & \multicolumn{2}{|c|}{$185-245$} \\
\hline & AHS & HSP & AHS & HSP & AHS & HSP & AHS & HSP & AHS & HSP & AHS & HSP \\
\hline F1 & 17.2 & 24.0 & 8.2 & 8.0 & 27.2 & 19.1 & 24.5 & 31.0 & 15.4 & 11.7 & 6.9 & 6.3 \\
\hline $\mathrm{F} 2$ & 18.4 & 30.7 & 8.3 & 6.1 & 26.5 & 14.5 & 25.0 & 29.8 & 15.2 & 11.8 & 7.3 & 7.0 \\
\hline F3 & 18.0 & 17.7 & 7.8 & 9.1 & 26.4 & 20.4 & 24.8 & 31.6 & 14.5 & 13.7 & 7.8 & 7.6 \\
\hline F4 & 17.8 & 18.0 & 8.9 & 9.6 & 26.4 & 23.7 & 22.0 & 24.0 & 16.5 & 14.0 & 7.5 & 11.5 \\
\hline
\end{tabular}

In the comparison of NMR spectra (Fig. 2 and Table 4) in the region 0-45 ppm, which corresponds to aliphatic groups (methyl and methylene), for both AHS and HSP fractions there was a reduction in the relative percentage of the largest AMS fraction (F2: $100 \mathrm{kDa}-0.45 \mu \mathrm{m})$ in relation to the smallest fraction $(\mathrm{F} 4:<30 \mathrm{kDa})$. These results are consistent with the high $\mathrm{H} / \mathrm{C}$ value (Table 2), and the fact that $\mathrm{HA}$ are formed by aromatic groups with long bonded aliphatic chains. Also, they had the highest $\mathrm{O} / \mathrm{C}$ value (Table 2), indicative of a more aliphatic nature and a smaller degree of humification in the smallest fractions.

Typical NMR signals for lignin at $152 \mathrm{ppm}(\mathrm{O}$-aryl C) were apparent for all fractions of AHS, mainly in fractions F1, F2 e F3; 55 ppm (methoxyl C) and 71 ppm (alkyl-O carbon) were apparent for all fractions of AHS and HSP; 33 ppm (alkyl chain) were apparent mainly in the F1 and F2 fractions of HSP, indicating a possible contribution from higher plants to both fractions of AHS and HSP. These regions were also found in Rosa et al. (2011) and Mylotte et al. (2015).

In the 60 to $110 \mathrm{ppm}$ region, related to the aliphatic groups bonded to oxygen, the percentages for the AHS fractions were similar for both fractions under study. Different behavior was observed in this region for the HSP fractions, in which the smallest AMS fractions 
(F4: $<30 \mathrm{kDa}$ ) showed a higher relative percentage. These results are in accordance with the proposal of Piccolo et al. (2001), which suggests that FA are formed with higher concentrations of bonded oxygen groups, giving them a repulsive character with the formation of smaller aggregates than those in the HA.

The NMR results are in accordance with those showed in Tables 1 and 4, in which the smallest AMS fractions (F3 and F4) for both AHS and HSP presented a higher amount of FA than of HA. This behavior was confirmed by the results observed in the region of carboxyl groups and esters (160-185 ppm). In the region where aromatic groups are found (110-160 ppm), the AHS and HSP with highest AMSs showed higher relatives percentages. A reduction in the relative percentage of the region corresponding to oxygenated aliphatic carbons and an increase in the relative percentage in the aromatic carbons region indicated an advance in the humification stage, characteristic of HA, which is verified in the largest AMS fraction (F2: $100 \mathrm{kDa}-0.45 \mu \mathrm{m})$ of AHS. In the region characteristic of carbonyl carbon (185-245 ppm), the lowest relative percentage was found for the F1 $(<0.45 \mu \mathrm{m})$ and F2 fraction $(100 \mathrm{kDa}-0.45 \mu \mathrm{m})$ for both AHS and HSP. This indicates that the content of oxygenated groups is lower in the largest fractions. For the AHS, the relative percentage of carbonyl carbon was similar for all fractions. The opposite was observed for the smallest fraction $(\mathrm{F} 4:<30 \mathrm{kDa})$ of HSP. Thus, differences between the characteristics of AHS and HSP were revealed.

\section{CONCLUSIONS}

Differences between the characteristics of AHS and HSP were verified. For the F1 fraction of AHS, the FA percentage was higher than HA, whereas the opposite was observed for the HSP. In smaller AMS fractions, for both AHS and HSP, the presence of FA was higher than that of HA. As there is a higher percentage of FA in the AHS, there is a higher number of oxygenated functional groups and higher number of aliphatic chains than in the HSP fractions. This behavior was confirmed by the results observed in the regions of carboxyl groups and esters (160 to $190 \mathrm{ppm}$ ) and aliphatic groups bonded to oxygen (60 to $110 \mathrm{ppm})$ by ${ }^{13} \mathrm{C} \mathrm{NMR}$ and IFTR (band around 3400 and $1400 \mathrm{~cm}^{-1}$ ). The elemental analysis (high $\mathrm{H} / \mathrm{C}$ and $\mathrm{O} / \mathrm{C}$ values) and UV/Vis spectroscopy (lower ratio $\mathrm{E}_{4} / \mathrm{E}_{6}$ and $\mathrm{E}_{2} / \mathrm{E}_{3}$ ) indicated that the smallest AMS fractions, both AHS and HSP, had greater aliphaticity and the lowest aromaticity and condensation degree. Such results have confirmed the theory that proposes that HS could be small and heterogeneous molecules of several origins that would self-organize in a supramolecular conformation, whose molecular association is variable and depends on the chemical nature. Due to the differences observed between AHS and HSP, the spectroscopic and physical-chemical characterization of these substances are indispensable in different studies, such as in water treatment and interaction of the AHS with micropollutants.

\section{REFERENCES}

ARAÚJO, A. B.; ROSA, A. H.; ROCHA, J. C.; ROMÃO, L. P. C. Metal distribution and characterization of exchange constants between metal species and aquatic humic fractions with different molecular sizes. Química Nova, v. 25, p. 1103-1107, 2002. http://dx.doi.org/10.1590/S0100-40422002000700011

BRAVARD, S.; RICHI, D. Characterization of fulvic and humic acids from an OxisolSpodosol toposequence of Amazonia, Brazil. Geoderma, v. 48, p. 151-162, 1991. https://doi.org/10.1016/0016-7061(91)90013-J 
CAMPOS, S. X.; AZEVEDO, E. R.; TITO, B.; VIEIRA, E. M.; BERNARDO, L. D. Color removal by coagulation, flocculation and sedimentation from water containing humic substances with different apparent molecular sizes. Journal of Water Supply: Research and Technology - AQUA, v. 56, p. 327-333, 2007. http://doi.org/10.2166/aqua.2007.009

DIALLO, M. S.; SIMPSON, A.; GASSMAN, P.; FAULON, J. L.; JOHNSON, J. H.; GODDARD, W. A. et al. 3-D. Structural modeling of humic acids through experimental characterization, computer assisted structure elucidation and atomistic simulations. Environmental Science \& Technology, v. 37, p. 1783-1793, 2003. http://doi.org/10.1021/es0259638

ESTEVES, V. I.; OTERO, M.; DUARTE, A. C. Comparative characterization of humic substances from the open ocean, estuarine water and fresh water. Organic $\begin{array}{lllll}\text { Geochemistry, } & \text { v. } & 40, & \text { p. } & 942-950,\end{array}$ https://doi.org/10.1016/j.orggeochem.2009.06.006

FICHER, T. Humic supramolecular structures have polar surfaces and unipolar cores in native $\begin{array}{llllll}\text { soil. Chemosphere, } & \text { v. } 2017 .\end{array}$ https://doi.org/10.1016/j.chemosphere.2017.05.125

FONG, S. S.; MOHAMED, M. Chemical characterization of humic substances occurring in the peats of Sarawak, Malaysia. Organic Geochemistry, v. 38, p. 967-976, 2007. https://doi.org/10.1016/j.orggeochem.2006.12.010

FUENTES, M.; BAIGORRI, R.; GONZALEZ-GAITANO, G.; GARCIA-MINA, J. M. The complementary use of 1H NMR, 13C NMR, FTIR and size exclusion chromatography to investigate the principal structural changes associated with composting of organic materials with diverse origin. Organic Geochemistry, v. 38, p. 2012-2023, 2007. https://doi.org/10.1016/j.orggeochem.2007.08.007

GARCÍA, A. C.; SOUZA, L. G. A.; PEREIRA, M. G.; CASTRO, R. M.; GARCÍA-MINA, J. M.; ZONTA, E. et al. Structure-Property-Function Relationship in Humic Substances to Explain the Biological Activity in Plants. Scientific Reports, v. 6, 20798, 2016. https://dx.doi.org/10.1038\%2Fsrep20798

GONZÁlEZ-PÉREZ, M.; TORRADO, P. V.; COLNAGO, L. A.; MARTIN-NETO, L.; OTERO, X. L.; MILORI, D. M. B. P. et al. 13C NMR and FTIR spectroscopy characterization of humic acids in spodosols under tropical rain forest in southeastern $\begin{array}{llllll}\text { Brazil. Geoderma, } & \text { v. } & 146, & \text { p. } & \text { 425-433, }\end{array}$ https://doi.org/10.1016/j.geoderma.2008.06.018

MCDONALD, S.; BISHOP, A. G.; PRENZLER, P. D.; ROBARDS, K. Analytical chemistry of freshwater humic substances. Analytica Chimica Acta, v. 527, p. 105-124, 2004. https://doi.org/10.1016/j.aca.2004.10.011

MUSCOLO, A.; SIDARI, M.; NARDI, S. Humic substance: Relationship between structure and activity. Deeper information suggests univocal findings. Journal of Geochemical Exploration, v. 159, p. 57-63, 2013. https://doi.org/10.1016/j.gexplo.2012.10.012

MYLOTTE, R.; VERHEYEN, V.; REYNOLDS, A.; DALTON, C.; PATTI, A. F.; CHANG, $\mathrm{R}$. R. et al. Isolation and characterisation of recalcitrant organic components from an estuarine sediment core. Journal of Soils and Sediments, v. 15, p. 211-224, 2015. http://doi.org/10.1007/s11368-014-0970-9 
NUZZO, A.; SÁNCHEZ, A.; FONTAINE, B.; PICCOLO, A. Conformational changes of dissolved humic and fulvic superstructures with progressive iron complexation. Journal $\begin{array}{lllllll}\text { of Geochemical } & \text { Exploration, } & \text { v. } & 129, & \text { p. } & 1-5,\end{array}$ https://doi.org/10.1016/j.gexplo.2013.01.010

PASCHOALATO, C. F. P. R.; TRIMAILOVAS, M. R.; DI BERNARDO, L. Formação de subprodutos orgânicos halogenados nas operações de pré-oxidação com cloro, ozônio e peroxônio e pós-cloração em água contendo subtância húmica. Engenharia Sanitária e Ambiental, v. 13, p. 313-322, 2008. http://producao.usp.br/handle/BDPI/4348

PEURAVUORI, J.; PIHLAJA, K. Molecular size distribution and spectroscopic properties oh aquatic humic substances. Analytica Chimica Acta, v. 337, p. 133-149, 1997. https://doi.org/10.1016/S0003-2670(96)00412-6

PICCOLO, A. The supramolecular structure of humic substances. Soil Science, v. 166, p. 810-832, 2001.

PRAMANIK, P.; KIM, P. J. Fractionation and characterization of humic acids from organic amended rice paddy soils. Science of The Total Environment, v. 466-467, p. 952-956, 2014. https://doi.org/10.1016/j.scitotenv.2013.07.115

RIGOBELLO, E. S.; DANTAS, A. D. B.; DI BERNARDO, L.; VIEIRA, E. M. Influence of the apparent molecular size of aquatic humic substances on colour removal by coagulation and filtration. Environmental Technology, v. 32, p. 1767-1777, 2011. http://dx.doi.org/10.1080/09593330.2011.555423

ROCHA, J. C.; OLIVEIRA, L. C.; SARGENTINI, E. J.; ROSA, A. H.; SIMÕES, M. L.; MARTIN-NETO, L. et al. The influence of seasonalness on the structural characteristics of aquatic humic substances extracted from Negro River (Amazon state) waters: interactions with $\mathrm{Hg}(\mathrm{II})$. Journal of the Brazilian Chemical Society, v. 18, p. 860-868, 2007. http://dx.doi.org/10.1590/S0103-50532007000400028

ROSA, A. H.; ROCHA, J. C.; FURLAN, M. Substâncias húmicas de turfa: Estudo dos parâmetros que influenciam no processo de extração alcalina. Química Nova, v. 23, p. 472-476, 2000. http://dx.doi.org/10.1590/S0100-40422000000400008

ROSA, J. M.; GONZÁLEZ-PÉREZ, J. A.; GONZÁLEZ-VILA， F.; KNICKER, J. H., ARAÚJO, M. F. Molecular composition of sedimentary humic acids from South West Iberian Peninsula: A multi-proxy approach. Organic Geochemistry, v. 42, p. 791-802, 2011. https://doi.org/10.1016/j.orggeochem.2011.05.004

SACHS, S.; BERNHARD, G. Humic acid model substances with pronounced redox functionality for the study of environmentally relevant interaction processes of metal ions in the presence of humic acid. Geoderma, v. 162, p. 132-140, 2011. https://doi.org/10.1016/j.geoderma.2011.01.012

SAMIOS, S.; LEKKAS, T.; NIKOLAOU, A.; GOLFINOPOULOS, S. Structural investigations of aquatic humic substances from different watersheds. Desalination, v. 210, p. 125-137, 2007. https://doi.org/10.1016/j.desal.2006.05.038

SCHNECKENBURGER, T.; LATTAO, C.; PIGNATELlO, J. J.; SCHAUMANN, G. E.; THIELE-BRUHN, S.; CAO, X. et al. Preparation and characterization of humic acid cross-linked with organic bridging groups. Organic Geochemistry, v. 47, p. 132-138, 2012. https://doi.org/10.1016/j.orggeochem.2012.03.014 
SILVERSTEIN, R. M.; BONLER, G. C.; MORRIL, T. C. Spectrophotometric identification of organic compounds. Rio de Janeiro: Guanabara Koogan, 1994.

STEVENSON, F. J. Humus chemistry: genesis, composition, reactions. $2^{\text {nd }}$ ed. New York: John Wiley \& Sons, 1994.

SUTTON, R.; SPOSITO, G.; DIALLO, M. S.; SCHULTEN, H.-R. Molecular simulation of a model of dissolved organic matter. Environmental Toxicology and Chemistry, v. 24, p. 1902-1911, 2005. http://doi.org/10.1897/04-567R.1

THURMAN, E. M.; MALCOLM, R. L. Preparative isolation of aquatic substances. $\begin{array}{lllllll}\text { Environmental Science \& Technology, v. } & 15, \quad \text { p. } & 463-466, & 1981 .\end{array}$ http://doi.org/10.1021/es00086a012

TRAINA, S. J.; NOVAK, J.; SMECK, N. E. An ultraviolet absorbance method of estimating the percent aromatic carbon content of humic acids. Journal of Environmental Quality, v. 19, p. 151-153, 1990. http://doi.org/10.2134/jeq1990.00472425001900010023x

VERGNOUX, A.; DI ROCCO, R.; DOMEIZEL, M.; GUILIANO, M.; DOUMENQ, P.; THÉRAULAZ, F. Effects of forest fires on water extractable organic matter and humic substances from Mediterranean soils: UV-vis and fluorescence spectroscopy approaches. Geoderma, v. 160, p. 434-443, 2011a. https://doi.org/10.1016/j.geoderma.2010.10.014

VERGNOUX, A.; GUILIANO, M.; DI ROCCO, R.; DOMEIZEL, M.; THERAULAZ, F.; DOUMENQ, P. Quantitative and mid-infrared changes of humic substances from burned soils. Environmental Research, v. 111, p. 205-214, $2011 \mathrm{~b}$. https://doi.org/10.1016/j.envres.2010.03.005

WAGNER, M.; SCHMIDT, W.; IMHOF, L.; GRÜBEL, A.; JAHN, C.; GEORGI, D. et al. Characterization and quantification of humic substances 2DFluorescence by usage of extended size exclusion chromatography. Water Research, v. 93, p. 98-109, 2016. https://doi.org/10.1016/j.watres.2016.01.050

YANG, F.; HUANG, Q.; LI, J.; ZHU, X. Characterization of chromophoric dissolved organic matter in the Yangtze estuary by absorption and fluorescence spectroscopy. Journal of Environmental Science for Sustainable Society JESSS, v. 1, p. 55-60, 2007. http://doi.org/10.3107/jesss.1.55 